\title{
Engendered Violence Against Afghan Women in Atiq Rahimi's $A$ Thousand Rooms of Dream and Fear
}

\author{
Seyedeh Robabeh Zabihzadeh ${ }^{1}$ \\ ${ }^{1}$ School of Language Studies and Linguistics, Universiti Kebangsaan Malaysia, Bangi, Malaysia \\ Correspondence: Seyedeh Robabeh Zabihzadeh, School of Language Studies and Linguistics, Universiti \\ Kebangsaan Malaysia, Bangi, Malaysia. E-mail: r.zabihzadeh@yahoo.com
}

\author{
Received: March 17, 2020 Accepted: April 20, 2020 Online Published: April 27, 2020 \\ doi:10.5539/ells.v10n2p57 URL: https://doi.org/10.5539/ells.v10n2p57
}

\begin{abstract}
The universal concern of domestic violence against women in its various manifestations came to the center of scholarly attention due to its harmful effects and consequences on the lives of thousands of women worldwide. This umbrella term that refers to any form of physical, sexual, and psychological abuse against women is the result of gender-based power imbalance and sexist inequalities in societies where patriarchal norms hold sway. However, the enormity and severity of the problem is more profound in third-world countries where governing policies are determined by traditional and religious doctrines. Afghanistan is one such third-world country where woman's oppression and abuse originate from the reigning religious principles that dominate its culture, society and politics. Nevertheless, there is a recent trend among literary figures of the Afghan Diaspora in highlighting the plight of Afghan women in Afghanistan through the medium of fiction. This paper therefore intends to investigate the manifestations of domestic violence against women in the Afghan context through a reading of Atiq Rahim's novella, A Thousand Rooms of Dream and Fear (2007). Rahimi's novella narrates the story of a male protagonist named Farhad and simultaneously highlights the miserable living conditions of the Afghan people, particularly the lives of Afghan women during the turbulent period of the Soviet Invasion as well as the many internal political upheavals that followed soon after. Using feminist literary criticism, the present paper shall discuss the depictions of three prominent forms of domestic violence against women as experienced by the female characters in the novella, namely physical, sexual and psychological violence that have shaped them into oppressed, silenced and traumatized individuals.
\end{abstract}

Keywords: physical abuse, sexual abuse, psychological abuse, Afghan fiction, Atiq Rahimi

\section{Introduction}

Violence against women involves "physical, sexual and psychological violence occurring in the family, including battering, sexual abuse of female children in the household, dowry-related violence, marital rape, female genital mutilation and other traditional practices harmful to women, non-spousal violence and violence related to exploitation" (UNICEF, 2000). Although domestic violence against women exists worldwide in various manifestations, it is more prominent in third-world countries such as Afghanistan, where society, culture and politics are based on male supremacy and subsequent marginalization of women. In such countries, women are degraded as inferior beings, making their conditions more deplorable and exposing them to many forms of violence. Therefore, Afghan women are considered as a vulnerable population based on a definition that refers to women "who share some common characteristic not held by the rest of the population and who are uniquely vulnerable with respect to risk and/or experiences surrounding violence" (Brownridge, 2009, p. 1).

Due to foreign invasions, poverty, socio-economical instability and political upheaval, women in Afghanistan face very high rates of violence. In fact, Afghan women are "largely known as one of the most oppressed groups of women in the world" (Bezhan, 2008, p. 373). Therefore, portraying the deteriorating condition of basic human rights, especially those of women in Afghanistan, has become a crucial concern for Afghan diasporic writers such as Atiq Rahimi. According to Tiemensma (2010), literature portrays one's society and culture through the agency of the fictional characters so it can be postulated that Rahimi's fiction is the illustration of women's social and moral degeneration as well as a portrayal of the violence they encounter in androcentric Afghanistan. Rahimi's female characters are represented by overwhelming oppression; however, they are given a voice to resist and overcome suppression and gender-based discrimination. Patriarchal social structures of Afghanistan in 
general, and men in particular, "suppress and limit womanhood in line with the male interpretation of what constitutes being female" (Bezhan, 2008, p. 374). In addition, such gender-discriminative practices of Afghan society deny the presence of domestic violence, or minimize and trivialize the extent of the problem or even vindicate its existence.

The purpose of this study is to examine the forms of domestic violence against women depicted by Rahimi in his novella $A$ Thousand Rooms of Dream and Fear (2007). As such, this study explores Rahimi's narrative in articulation of domestic violence and his portrayal of women's position in Afghan society, which is an adoption of their real life condition as "there is truth-literal truth - in fiction since most fictional stories play out against a background of fact" (Davies, 2010, p. 49). The kinds of violence that the female characters in the selected text endure are generally imposed by either domination of the patriarchal society of Afghanistan, or misinterpretations of Islamic law, or in a narrower sense, by the male characters in the story. War as a present and effective factor in the story intensifies the plight of the female characters and deteriorates their living conditions. By living in Afghanistan during times of war, women are vulnerable to several forms of domestic violence. To be more specific, this study aims to show how Rahimi's depictions of domestic violence against women in $A$ Thousand Rooms of Dream and Fear coincides with the actual high rate of the violation of women's basic rights as human beings in Afghanistan. It emphasizes on the necessity to end domestic violence against women by making appropriate laws in order to prevent, investigate, and prosecute perpetrators as well as consider such violations against women "as an offence under Islam and a crime under national law" (Nijhowne \& Oates, 2008, p. 57), especially within the context of Afghanistan.

\section{Literature Review: Domestic Violence in Afghanistan}

A review of available literature on the topic of this study, namely engendered violence against Afghan women in Atiq Rahimi's A Thousand Rooms of Dream and Fear, reveals that for a better understanding of the said topic, it is crucial to examine past scholarly researches conducted on the subject matter. A substantial number of researches have been done on the issue of domestic violence against women from various perspectives worldwide, but not many have focused on the context of Afghanistan. This section will concisely highlight previous academic scholarship on the existence of violence against women in Afghanistan.

Violence against women in the home is so prevalent and pervasive in Afghanistan that practically every Afghan woman will experience it in her lifetime. Diya Nijhowne and Lauryn Oates (2008) in a report, entitled Living with Violence: A National Report on Domestic Abuse in Afghanistan published by Global Rights: Partners for Justice, present the findings of surveys on domestic violence conducted in 2006 with women in 4,700 households in 16 provinces located across Afghanistan. According to the report, the rate at which Afghan women have undergone at least one form of violence, be it physical, sexual or psychological, is astoundingly high, at $87.2 \%$; the situation remains bleak as the same report also states that the number of Afghan women claiming to have suffered more than one form of violence clocks in at an alarming rate of $62 \%$. Such disquieting contents of the report, as presented by Nijhowne and Oates, are largely due to the general view in Afghan society of domestic violence as a very conventional and everyday matter that has subsequently compelled Afghan women to not only accept it as part and parcel of their lot in life, but also to remain silent about the miseries they have had to endure as a result of domestic violence. As such, despite having suffered various forms of violence in the hands of their spouses and, to an extent, other male relatives at home, a great many Afghan women would instead affirm that they are generally satisfied with their station in life as married women. In their report, Nijhowne and Oates have also state that domestic violence, as a form of violation against human rights, can only be significantly prevented in Afghan society if the Afghan state itself, given its powers in legislation, is actively involved in curbing the problem by scrutinizing cases of domestic violence and subsequently punishing those responsible for inflicting it. Nevertheless, this will be an uphill task, as substantial measures, such as the financing and building of women's shelters to house battered women who have escaped their spouses, as well as teaching the police to treat domestic abuse as a criminal offence and attend to its victims with compassion, in addition to the beefing up of the public health system so that it may take the appropriate actions in treating victims of domestic violence, need to be resorted to. Last but not least, Afghanistan's bodies of jurisdiction and legislation must be compelled to investigate, try and penalize the perpetrators of domestic violence. In fact, Nijhowne and Oates (2008) have stated that Global Rights has vouched for the body of legislation in Afghanistan to subject itself to reform and change where domestic violence is concerned, in the hopes that domestic violence be given due recognition as a criminal and religious offence. They are also of the view that such a step is highly necessary to not only alter the prevailing perception of domestic violence as a private matter in which state jurisdiction has no power of intervention, but also to keep it deeply rooted in dimensions of the public sphere, namely the bodies of state jurisdiction and legislation, where it will be deemed rightly as a crime. 
That being said, Hatfield et al. (2008) in Women's Participation in Domestic Violence Health Policy Development: Afghanistan Component, also present an argument with regards to the role of Afghan women in the institution of family, as well as domestic violence and policy development, notably that of health policies in Afghanistan. In this context, they have highlighted the miserable conditions many Afghan women face, most notably the staggering rate of domestic violence inflicted upon them. In their view, this does not come as much of a surprise, especially for a developing country like Afghanistan that has also endured nearly four decades of war, which has profoundly eroded its bodies of jurisdiction, legislation, society, politics, education and healthcare. The issue of domestic violence against women has been brought to public attention only in recent times, notably in the years of Karzai's administration, when Karzai himself initiated the move to prioritize on women's rights as part and parcel of his government's efforts to introduce democracy in Afghanistan. Unfortunately, the rife scenario shows that years of war and poverty as well the collapse of major institutions have resulted in the grave brutalization of Afghan women, who are still subjected to a myriad of acts of gender-based violence, notably physical abuse, trafficking and rape. This sorry situation, according to Hatfield et al. (2008), is a lot worse in the rural areas, where reports of widespread underage and forced marriages of girls are abounded. In their concluding statement, Hatfield et al. elucidate that, since Afghanistan is home to a patriarchal society and an inefficient criminal justice system, there is judicial amnesty for those who partake in violence against women. This not only allows violence against women to thrive, but also enables perpetrators to continually inflict such violence with impunity, given that their actions are not subjected to legal or judicial inquiry.

\section{Domestic Violence Against Women in Fiction}

Of late, domestic violence against women, a worldwide concern with various harmful consequences on the victims and consequently on the society - as the victims constitute a large proportion of population - has become a widely-depicted subject among writers such as Atiq Rahimi. Zabihzadeh et al., in their 2015 study entitled Domestic Violence against Women in Atiq Rahimi's The Patience Stone, refer to the significant role Rahimi has played in enlightening and increasing awareness of Afghan women through highlighting the plights and miseries of women in Afghanistan in his novella The Patience Stone. They also analyze the physical, sexual and psychological abuse endured by the female protagonist of the story as a result of the patriarchal norms prevalent in Afghan society, notably during the years of Taliban rule. They argue that Rahimi's articulation of afghan women through his nameless heroine reveals the despondent conditions of women in Afghanistan. According to Zabihzadeh et al. (2015), Afghan women live in the shadow of patriarchy and gender-based violence that define women as inferior beings in need of male protection and control. They further postulate that based on Rahimi's depiction, women in Afghanistan are trapped in a conventional society that places men at a greater privilege over women, to the extent that women are deprived of their basic human rights and live in a worrisome situation.

Pangestu and Dharma (2014), in their article entitled Confession without Borders: 1st Wave Feminism against Woman's Right Disproportion in Atiq Rahimi's The Patience Stone, argue that Rahimi's depiction of the anonymous Afghan heroine of the story in The Patience Stone portrays the harsh realities of women's worrisome difficulties as well as wretched lives they lead in their homeland. In this context, Afghan women are treated as the second sex; hence, they are expected to be subservient and submissive. Although the rebellious heroine of The Patience Stone vents out her anger, hatred and sufferings, she only gains the courage to do so when her husband is unconscious. That being said, Pangestu and Dharma have also discussed Rahimi's depictions of marriage and women's roles in choosing their spouses. In this context, they state that marriage is portrayed as a form of slavery in the novella, notably as the heroine of the story as well as her sister and aunt are exchanged in acts of forced and arranged marriages perpetrated by their male elders. Furthermore, women are depicted in several parts of the story as individuals objectified to fulfill male pleasure and sexual satisfaction. Finally, Pangestu and Dharma have also raised another issue widely depicted in the novella, namely that of how Islamic rules and principles, which they view as in favor of men and thus indifferent towards women's rights, are practiced in Afghan society.

Hussain, in his 2015 paper Women in Conflict: A Study of Afghan English Novels (With Special Reference to Khalid Hosseini's A Thousand Splendid Suns and Atiq Rahimi's The Patience Stone), divulges the hardship that Afghan women endure in androcentric Afghanistan. He states that Afghan women are the most vulnerable members of society in war-torn Afghanistan. In fact, they endure double victimization and violence as "part of civilian population and due to their gender" (p. 82). He further claims that poverty, war, and political upheavals in Afghanistan, as depicted in Rahimi and Hosseini's literary productions, have forced women to suffer silently from domestic violence by the male members of the family, be it their husbands, fathers, even their sons. He also adds that Afghan writers, such as Atiq Rahimi and Khalid Hosseini, are notable for depicting the daily agonies of 
Afghan people, particularly women, who are "caught in an unending whirlpool of violence and carnage of war" (p. 83).

\section{Conceptual Theory}

Feminism can be defined as "a set of theories about women's oppression and a set of strategies for change" (Daly \& Chesney-Lind, 1988, p. 502). It is based on the ideology that supports political, economic, legal and social justice for women with a profound aspiration to eradicate "all forms of gender inequality and their injurious consequences such as violence against women" (DeKeseredy \& Schwartz, 2001, p. 12). Accordingly, feminism focuses on the concept of patriarchy and gender inequality as the major factors that contribute to the occurrence of violence against women. In fact, feminism attempts to establish equal opportunities for women in society, so that they can confront and eradicate every form of violence directed towards them as a result of gender inequality and patriarchy. Feminist literary criticism studies women's suppression, degradation and marginalization "in a patriarchal culture, a culture organized in favor of men" (Behtash \& Sajjadi, 2012, p. 108). From a feminist standpoint, men inflict violence against women to display their supremacy and to maintain power and control over women (Dutton, 2011; Hanmer, Radford, \& Stanko, 2013; Hanmer \& Itzin, 2013). This increasingly egregious global issue affects women worldwide, regardless of their socioeconomic status and age group. Nevertheless, women who live in destructive situations such as war, as well as women in impoverished parts of the world and women from ethno-religious minorities are more vulnerable to various forms of violence (True, 2012). Violence against women in its various forms, including but not limited to physical, mental, verbal, sexual, emotional, psychological and economic abuse, is an ongoing pattern of actions perpetuated "as a means of enforcing control and power" (Cooper-White, 2012, p. 81) over women. However, victimized women who suffer from a cycle of violence and a pattern of repeated abusive behaviors seek explanations to justify the violence they endure and may even exhibit self-blaming attitudes (Hanmer, \& Itzin, 2013). That being said, the majority of victims tend to keep the acts of domestic abuse inflicted against them a private matter within the parameters of home.

In this study, Afghan women, as portrayed by Rahimi, are subjugated and suppressed at both private and public spheres. Rahimi in his novella, A Thousand Rooms of Dream and Fear, describes the high incidence of violence against women in Afghanistan and provides a vivid picture of Afghan women's sorrows and burdens in life. This study examines three prevailing forms of abuse namely physical, psychological and sexual abuse in Rahimi's selected fiction. According to Lundberg-Love and Marmion (2006), physical abuse as the most typical from of abuse occurs when a man uses his physical power to dominate a woman. It comes in various forms, such as "slapping, hitting, kicking, burning, punching, choking, shoving, beating, throwing things, locking a person out of the house, restraining" (Lundberg-Love \& Marmion, 2006, p. 5), all of which result in physical injuries or endangering the victim.

The other form of abuse, which will also be examined in Rahimi's novella, is psychological abuse. As its namesake suggests, psychological abuse affects women emotionally and leaves psychological scars on its victims. Paludi and Denmark (2010, p. 112) argue that psychological abuse, be it verbal or nonverbal, refers to a pattern of behaviors "designed to control and subjugate another person through the use of fear, humiliation, guilt, manipulation, or other nonphysical means". That being said, Lundberg-Love and Marmion (2006, p. 6) postulate that psychological abuse may appear in diverse forms, such as "doing or saying things to shame, insult, ridicule, embarrass, demean, belittle, or mentally hurt" the victim. They further state that psychological abuse can also include mocking the victim for her gender, ignoring her feelings and emotional needs, insulting her with such terms as "fat, lazy, stupid, bitch, silly, ugly" (p. 6), disapproving of her behavior and actions, separating her from her family, friends and children, humiliating her in front of others, withholding money, affection, attention or permission, criticizing her repeatedly, forcing her to stay in the abusive relationship, destroying her sense of self-worth and self-confidence, ridiculing her principles, values, traditions, race, and religion, intimidating her with threats of physical violence on her and/or her children and taking custody over them (Lundberg-Love \& Marmion, 2006). Over and above, in countries such as Afghanistan, where polygamous marriages are not only prevalent in society, but also permitted by constitutional law and religious principles, women suffer psychologically from unequal love and their emotional needs are subsequently denied (Karamagi et al., 2006).

Last but not least, sexual abuse is yet another common form of violence experienced by women and girls in Afghanistan, thanks in part to the patriarchal environment of the society they live in. Sadly, "a culture of impunity exists for sexual violence" (Sima Samar, cited in The Annual Report by Afghan Women's Network, 2009 , p. 2) in Afghanistan. Among the overwhelming majority of Afghans, this form of abuse has been constantly perceived as a private matter meant to be confined within the family. As such, regarding the occurrences of sexual abuse, "state institutions refuse to intervene in some cases while in other cases, they 
promote the ownership of females in the family by men" (Sima Samar, cited in The Annual Report by Afghan Women's Network, 2009, p. 2). According to the Annual Report by Afghan Women's Network, "17 percent of the [Afghan] women are sexually abused by their husbands, in other words marital rape" $(2009$, p. 5). Afghan women are undoubtedly vulnerable to various forms of sexual abuse, even more so in marriage; nevertheless, such term cannot be found and does not exist in the national criminal or civil legislation in Afghanistan.

Generally, Afghan folk be it women or men believe that conferring issues associated to "sex and sexual violence as taboo, as women's sexuality is effectively controlled by men" (UNAMA \& OHCHR, 2009, p. 21). In Afghanistan, women are perceived as "the guardians of culture and the custodians of a family's "honor" (UNAMA \& OHCHR, 2009, p. 21). As such, victimized women who are subjected to sexual abuse are perceived as disgracing their families that bring shame to the family. Even in marital sexual abuse cases, women are expected to be submissive and they are given "no choice in terms of consenting to sexual intercourse with their spouse" (UNAMA \& OHCHR, 2009, p. 21). According to LaViolette and Barnett (2013), sexual abuse largely happens as a byproduct of the abuser's fear of loosing the partner. In order to reduce the fear, the perpetrator inflicts sexual violence against her [the victim] without considering her feelings, since he is only concerned with "alleviating his own discomfort" (LaViolette \& Barnett, 2013, p. 136). As Paludi and Denmark (2010) postulate sexual abuse takes various forms including using force to fulfill the abuser's sexual desires and forcing the victim to copulate with him against her will, whether or not the act is accomplished. McCue (2008) explores other forms of sexual abuse such as telling dirty jokes about the victim and her gender in her presence, considering women as sex objects, disregarding women's sexual needs, withholding sex and affection, forcing the victim to have sex despite her reluctance and opposition, touching her sexually in unpleasant ways, addressing the victim with sexually offensive words such as 'whore' or 'frigid', humiliating the victim for her sexual acts, forcing the victim to witness his sexual acts with others. Furthermore, to maintain their supremacy and power, men also inflict other forms of sexual abuse on women obliging the victim to copulate with others, hurting victim with rough sex using objects or weapons and finally mutilating her (McCue, 2008).

\section{Textual Analysis}

\subsection{Physical Abuse in A Thousand Rooms of Dreams and Fear}

In the novella $A$ Thousand Rooms of Dream and Fear, women's problems are viewed in a broader sense. The focus of novella is mostly on the societal conditions of Afghanistan and the way both men and women are affected by the suffocating atmosphere inside the borders of a conservative society damaged by war and poverty. Hence, no sign of physical abuse is seen in women's life, whereas a great quantity of the text is written about Farhad being battered by the soldiers.

However, war, aggression and conflicts affect the whole society and play crucial roles in the occurrence of violence in various ways. In times of war, all people are affected by its portentous consequences, even the individuals who are not directly involved in the war such as Farhad who is a student during the period of war and upheaval in Afghanistan. As such, it can be postulated that those who suffer the horrible outcomes of war are thus subjected to victimization not only on the grounds of ethnicity and faith, but also based on their level of proximity with the battlefield (Leanage, 2010). Undeniably, in times of war, people are gradually accustomed to violence as it is increasingly interwoven in their daily lives. The mutually destructive savagery, vengeance and hatred invested in war, in addition to shortages of bare necessities such as food and medical supplies, a state of constant fear and panic, as well as profound disturbances in what is considered as everyday life are all potential causes behind the severe mental trauma and personal inner turmoil resulting from war, which are thus responsible for acute changes in personality and/or behavior, notably in the form of violent outbreaks (Leanage, 2010). Therefore, people who experience war and its brutality, such as Farhad, are at risk of perpetrating domestic violence at some point in their own lives. That being said, the wrongs and the trauma that they have endured in times of war can be sufficiently cited as justification for their acts of domestic violence. To sum it up, it can be deduced that Farhad, as a victim of physical abuse during the war, has the capacity to show aggression and violence in his future marital life, which are manifested in his abnormal mental conditions shaped by years of brutal mistreatment. As the victim of insults and battering by the soldiers, he can therefore evolve into a potential abuser due to the severity of his experiences.

\subsection{Psychological Abuse in A Thousand Rooms of Dreams and Fear}

In the novella $A$ Thousand Rooms of Dream and Fear (2007), Farhad's mother and Mahnaz have both undergone situations in which they are psychologically abused. Their respective experiences of psychological abuse, however, are different in terms of their positions within the institution of family. To begin with, Farhad's mother, as stated by Farhad in the story, has been subjected to polygamy. In relation to this, previous academic scholarship has revealed that violence against women is profound in "polygamous marriages because of unequal love, neglect and 
jealousy" (Karamagi et al., 2006). Here, the unequal treatment of spouses in polygamous marriages gives rise to many forms of violence, such as psychological abuse. As a consequence of unequal treatment by the husband in polygamous marriages, women's emotional needs are ignored. In the story, the emotional needs and feelings of Farhad's mother have been neglected in the course of her marriage by her polygamous husband, as he prefers to live with his second wife, eventually abandoning her. In fact, she has no choice and grounds to fulfill her emotional needs and desires, as her husband is the decision maker in the family, and she is only a submissive recipient of the situation. Having been abandoned without being divorced, Humaira-Farhad's mother-is forced to live a life deprived of any emotion and love, as exemplified below.

Two years ago, my father took a second wife, younger than my mother. Then, after the coup, he fled to Pakistan. He never divorced my mother, he simply abandoned her..." (p. 40)

In the following extract, Farhad has implied that his father never loved his mother, thereby pointing out that she was denied love and emotions during her marital life. As stated earlier, denying women's emotional needs is a form of psychological abuse. The following excerpt from the novella reinforces Humaira's emotional abuse in her marriage.

Truth is, my father never loved my mother at all. (p. 65)

Farhad's mother, as a married woman and as the mother of three children, has been neglected by her husband, both emotionally and economically, so much so that she is left with no financial support. The extent to which Farhad's mother is emotionally hurt can easily be seen in Farhad's explanations:

... on the day my father decided to take a second wife. My mother wept-and then her face once again assumed its mask of fear." (p. 64)

According to Farhad's grandmother, his mother "was born with a terrified face" (p. 64). For Farhad, it seems that his mother has always worn a mask of fear. The mask of fear, as explained by Farhad in the story, is his mother's facial expression, worn out and frightened by her husband's misdeeds, one of them being his act of taking in another wife. Furthermore, the fear is also a result of the lack of love in her marriage as she was in love with her cousin, prior to betrothal. Therefore, her emotions and desires are ignored by her husband, not just in sex, but in every other aspect of her marital life.

Farhad believes that the motive for this second marriage is that his father did not notice any sign of anxiety and fear in his mother during their sexual intercourse. In this context, lack of distress in their sexual relationship and marital life is equivalent to fulfilling her emotional and sexual pleasures, which is unbearable for her husband, as exemplified below.

But what happened the day the fear vanished from my mother's face to make my father think of taking another wife? Probably my father needed a woman to be scared of him in order to get turned on. And the day my mother stopped being terrified of having sex, my father's desire vanished. So he had to get himself another wife." (p. 65)

In the above extract, Humaira's husband is undoubtedly afraid of losing his superior image and control over her. By prodding at her sexual frustration to scar her emotions, he gets to retain his superiority and hegemony. That being said, he leaves her emotionally frustrated, torn and trapped the moment he finds his dominance under threat. Besides that, Farhad's mother is never given a chance to voice out her feelings, emotions, and opinions. Her story, as well as her conflicts with his father, in addition to the various forms of abuse that she has experienced, is narrated entirely through Farhad. Obviously, Farhad, as a man in the patriarchal society of Afghanistan, cannot understand and express the depth of his mother's miseries and sorrows. Nevertheless, his mother, as with many other women in Afghanistan, is silenced, marginalized and denied from expressing her feelings.

In addition, Farhad's mother is also a victim of psychological abuse while making love with her husband. In this context, she is denied sexual and emotional fulfillment by her husband. In fact, her husband cannot accept the fact that she is seeking love and emotion by way of sexual intercourse, as can be gleaned from in the following extract from the novella.

And maybe the day my mother lost the fear of having sex was the first time she ever enjoyed it. The first and the last time. (p. 65)

The justification behind this quotation is that Farhad's father left his mother due in part to the prevalent view that a woman who has no fear of her husband in sex is no longer a suitable wife. As men try to maintain their hegemony over women in every aspect of life, including in sex, they simply cannot admit that women have the same right to enjoy it. Therefore, when Farhad's father finds out that Humaira has emotionally and sexually felt fulfilled, he 
abandons her to seek and regain his superior image in another relationship. In a way, Humaira's feelings of pleasure during sex are viewed as a form of transgression by her husband, and he punishes Humaira for such a transgression by abandoning her. He subsequently leaves his wife and family and takes in a second wife to start a new life within his ideological framework in Pakistan, a framework within which women are constantly and repeatedly subjected to various forms of abuse.

Mahnaz, the other important female figure of the story, is assaulted by her deceased husband's family in order to fulfill their demands. Without the slightest attention to her feelings, her husband's family descends upon her house to take her son Yahya away from her. The patriarchal culture and traditional laws of Afghanistan disregard a mother's feelings towards her children and deprive her of her basic right to have custody over her own children in the absence or death of her husband. This cultural practice permits Mahnaz's mother-in-law and brothers-in-law to threaten her for taking guardianship of Yahya. According to Lundberg-Love and Marmion (2006), threatening a woman with custody of her own children is a manifestation of psychological abuse. When the mother-in-law as a representative of husband's family, faces Mahnaz's resistance, she insults and swears at Mahnaz for taking Yahya with her:

"You can do what you want, but I'm taking Yahya with me. I am not leaving my grandson in the care of a mad woman!” (p. 95)

Or

"So now you're so important, you have the audacity to throw me out of my own son's house. Mark my words, you'll regret..." (p. 96)

The mother-in-law, in the shadow of patriarchy, threatens Mahnaz and instills fear in her. Furthermore, by calling Mahnaz a "mad woman", she questions Mahnaz's ability to perform her motherly duties. As cited earlier by Lundberg-Love and Marmion (2006), putting down the victims' ability to fulfill her gender role as a wife or mother is an apparent indication of psychological abuse. Mahnaz's competence as a mother is negated by the in-laws and Afghanistan's legislation, as neither the former nor the later recognize the right of women to become guardians of their own children.

Dominated by her in-laws, Mahnaz feels oppressed and psychologically abused as her individual aspiration to live as a widow with the memory of her late husband in the company of her son, obviously goes against society's expectations. In Afghan society, under the pretext of safeguarding women's honor, it is not acceptable for a widow to live alone. In fact, a widow must be kept within the family and marry one of her unmarried brothers-in-law or become the second wife to a married brother-in-law. Mahnaz as a victimized woman in such a society is no exception. In fact, she has been stuck in the trap of forced marriage twice in her lifetime by people who have shown callous disregard for her needs and feelings, including her parents, who have forced her to marry a physically-disabled male cousin against her will. Despite his hearing and speech impediments, Mahnaz's parents arrange a marriage between him and Mahnaz. As a girl in androcentric Afghan society, Mahnaz is psychologically abused and frustrated because her feelings are neglected and she is denied her own say in deciding who to marry. Therefore, she escapes her predetermined destiny and runs away from her family home. She narrates the bitter story of her emotional abuse in the following excerpt:

So when I was a little girl they arranged for me to be married to my cousin. He was deaf and dumb... when I grew up, I had no choice but to marry my cousin. So I ran away and I married Yahya's father. (p. 115)

As Mahnaz trespasses the boundaries and conventions of patriarchal Afghan society by her escape from the parental house, she encounters more severe emotional violence from her own family when they disown her. They consider Mahnaz's escape as a threat to the family honor and status quo; therefore, they banish her and cut all ties with her.

The fact that women in patriarchal societies are viewed as objects possessed by men, both physically and psychologically, is made apparent through men's behavior towards them. In this context, women's emotional needs and feelings tend to be dismissed by men, as if women's emotions have no place in their lives and minds.

\subsection{Sexual Abuse in A Thousand Rooms of Dream and Fear}

Women all around the world get married and subsequently bear children and partake in a host of other wifely duties. The difference lies in the extent of patriarchy's role within a society, which ultimately confines and suppresses women in a particular mold to suit the ideology of male dominance. In the novella $A$ Thousand Rooms of Dream and Fear, Farhad's mother is one such woman. In the story, her husband uses sex as a weapon against her, to suppress and control her. The moment her husband feels that she is getting sexual pleasure from their martial intimacy, he decides to take another wife, preferably a woman who fears him. As mentioned earlier, 
McCue (2008) is of the opinion that ignoring and minimizing women's feelings and needs regarding sex, is a form of sexual abuse. Furthermore, withholding sex and affection is another act of sexual abuse. Farhad's mother suffers from both kinds of sexual abuse as her husband ignores her feelings and withholds sex with her as a way of abandoning her.

Rahimi narrates the common story of Humaira's victimization and her sexual frustration through Farhad, who recalls the excruciating story of his mother's sexual abuse, as exemplified below:

My father never loved my mother at all, he just fucked her. He'd get on top of her in the dark, close his eyes ... and get on with it. (p. 65)

Based on the above extract, it is evident that Farhad's mother has long been suppressed through sex. In this context, her role in the marriage is not that of an equal partner, but rather an object of sex. Her sole function as a wife is to just fulfill her husband's sexual desires whenever the whim suits him. Furthermore, by raping her, Farhad's father feels a great sense of power and dignity, as his mother is terrified of him and always afraid of having sex. Satisfaction of lust is crucial to Farhad's father, so much so that he gets himself another wife and abandons his wife and children for good.

\section{Conclusion}

The contemporary literature produced in Afghanistan as well as by Afghan diasporic writers, presents a kind of milieu where Afghan women stand as stereotypical victims of hard-nosed traditions, suffocated in the name of religion and oppressed by patriarchy. According to Hashim (2010, p. 31), the pragmatic practice that should be taken seriously in curbing domestic violence, "relates to making public the narratives of domestic violence". She believes that the only platform to seek an end to violence against women and children is to prepare the ground for exchanging the stories of violence that women endure. We have to stand against women's abuses and voice out the stories of violence they experience, in order to prepare "a safer and more loving environment for women" (Hashim, 2010, p. 31).

Portraying the plight of Afghan women is a mission, which cannot be handled in a monolithic way. Putting their situation within the feminist and psychological frameworks is only one side of the story. Their critical situation is the consequence of an entire cultural and civilizational phenomenon, which needs to be studied in communion with many aspects from various perspectives such as those pertaining to legislation, health and sociology. Rahimi's novella $A$ Thousand Rooms of Dream and Fear offers a depiction of the state of Afghan women where one feels compelled to study these at various levels. Not only that, it provides readers with the cultural and civilizational hermeneutics of the Afghan way of life. However, highlighting the issues related to women such as domestic violence, from the texts, will help readers to fully understand the sorrowful situation of women in Afghanistan. It is hoped that this study can make a step forward in eliminating violence against women in the world and particularly in Afghanistan by creating awareness among readers themselves.

\section{References}

Behtash, E. Z., \& Sajjadi, F. (2012). Literary Feminism in India. Journal of Subcontinent Researches, 4(11), $107-117$.

Bezhan, F. (2008). Obedient and resistant: Afghanistani women in Maryam Mahboob's short stories. Women's Studies International Forum, 31(5), 373-382. https://doi.org/10.1016/j.wsif.2008.08.002

Brownridge, D. A. (2009). Violence against women: Vulnerable populations. Routledge. https://doi.org/10.4324/9780203877432

Cooper-White, P. (2012). The cry of Tamar: Violence against women and the church's response. Fortress Press. https://doi.org/10.2307/j.ctt22nm7kg

Daly, K., \& Chesney-Lind, M. (1988). Feminism and criminology. Justice Quarterly, 5(4), 497-538. https://doi.org/10.1080/07418828800089871

Davies, S. (Ed.). (2010). Art and its messages: meaning, morality, and society. Penn State Press.

DeKeseredy, W. S., \& Schwartz, M. D. (2001). Definitional issues. Sourcebook on violence against women (pp. 23-34).

Dutton, D. G. (2011). Rethinking domestic violence. Ubc Press.

Hanmer, J., \& Itzin, C. (Eds.). (2013). Home truths about domestic violence: feminist influences on policy and practice-a reader. Routledge. https://doi.org/10.4324/9781315011585

Hanmer, J., Radford, J., \& Stanko, E. (Eds.). (2013). Women, Policing, and Male Violence (Routledge Revivals: 
International Perspectives). Routledge. https://doi.org/10.4324/9780203514771

Hashim, R. S. (2010). Eliminating domestic violence: issues and implications. The NIEW Journal: The Voices of the Nam Women, 2, 19-32.

Hatfield, J. et al. (2008). Women's Participation in Domestic Violence Health Policy Development: Afghanistan Component. Women's Domestic Violence Health Project.

Hussain, S. (2015). Women in Conflict: A Study of Afghan English Novels (With Special Reference to Khalid Hosseini's A Thousand Splendid Suns and Atiq Rahimi's The Patience Stone). Asian Journal of Multidisciplinary Studies, 3(9).

Karamagi, C. A., Tumwine, J. K., Tylleskar, T., \& Heggenhougen, K. (2006). Intimate partner violence against women in eastern Uganda: implications for HIV prevention. BMC Public Health, 6(1), 1. https://doi.org/10.1186/1471-2458-6-284

LaViolette, A. D., \& Barnett, O. W. (2013). It could happen to anyone. Sage.

Leanage, N. M. (2010). Domestic Violence in Sri Lanka: Its Causes and Consequences. The NIEW Journal: The Voices of the Nam Women, 2, 59-74.

Lundberg-Love, P. K., \& Marmion, S. L. (Eds.). (2006). "Intimate” violence against women: when spouses, partners, or lovers attack. Greenwood Publishing Group.

McCue, M. L. (2008). Domestic violence: A reference handbook. Abc-clio.

Nijhowne, D., \& Oates, L. (2008). Living with violence: A national report on domestic abuse in Afghanistan. Global Rights.

Paludi, M. A., \& Denmark, F. (Eds.). (2010). Victims of sexual assault and abuse: Resources and responses for individuals and families (vol. 1). Praeger Publishers.

Pangestu, T. H., \& Drama. D. B. (2014). Confession without Borders: 1st Wave Feminism against Woman's Right Disproportion in AtiqRahimi'sThe Patience Stone. Language Horizon, 2(1).

Rahimi, A. (2007). A thousand rooms of dream and fear. Vintage.

The Annual Report by Afghan Women's Network. (2009). Gender-based violence in Afghanistan.

Tiemensma, L. (2010). Books are windows, books are mirrors: multicultural collections for children and young adults opening new worlds. Manuscript, Midrand Grad Institute.

True, J. (2012). The political economy of violence against women. Oxford University Press. https://doi.org/10.1093/acprof:oso/9780199755929.001.0001

UNAMA \& OHCHR. (2009). Silence is Violence: End the Abuse of Women in Afghanistan. Kabul.

UNICEF. (2000). Domestic Violence against Women and Girls. Florence: Innocenti Research Center.

Zabihzadeh, S., Hashim, R. S., \& Gabriel Clement Chen Wei Chua. (2015). Domestic violence against women in Atiq Rahimi's The Patience Stone. GEMA: Online Journal of Language Studies, 15(3), 51-66.

\section{Copyrights}

Copyright for this article is retained by the author, with first publication rights granted to the journal.

This is an open-access article distributed under the terms and conditions of the Creative Commons Attribution license (http://creativecommons.org/licenses/by/4.0/). 